\title{
Fracture resistance of root-filled teeth after cavity preparation with conventional burs, Er:YAG and Er,Cr: YSGG lasers
}

\section{Purpose}

The aim of the present study is to compare the fracture resistance of teeth after access cavity preparation with conventional rotary burs, Erbium-doped yttrium aluminum garnet laser (Er:YAG) and Erbium, cromium: yttrium scandium gallium garnet laser (Er,Cr:YSGG) lasers.

\section{Materials and methods}

Fifty five intact mandibular molars were divided into 3 negative groups (groups 1, 2, $3 ; n=5$ for each), 3 study groups (groups $4,5,6 ; n=10$ for each) and 1 positive control group (intact teeth; $n=10$ ). Access cavities of groups 1,2 and 3 were prepared with conventional burs, Er:YAG laser and Er,Cr:YSGG laser respectively. After root canal obturation, their coronal portions were left non-restored. Access cavities of groups 4, 5 and 6 were prepared by using the same equipment but their coronal portions were restored with composite resinafter root canal obturation. Following thermocycling, fracture strength was evaluated with a Universal Testing Machine. Mean force at which each sample is fractured was recorded in Newton unit and statistically analyzed.

\section{Results}

Fracture resistance of group 7 (intact teeth) was significantly higher than all other groups ( $p<0.001$ ). Differences among the fracture resistance values of groups 4,5 and 6 were not significantly different but they were significantly higher than those of groups 1,2 and 3 ( $p<0.001$ ). No significant difference was found between Groups 1, 2 and 3 .

\section{Conclusion}

Preparing access cavities with either laser or bur has no effect on the fracture resistance of teeth with root canal treatment.

Keywords: Bur; cavity preparation; Er,Cr:YSGG; Er:YAG; fracture resistance

\author{
Uğur Aydın', \\ Fatih Aksoy ${ }^{2}$, \\ Samet Tosun ${ }^{3}$
}

\section{Introduction}

Fracture is an important risk for endodontically treated teeth (ETT) (1). These teeth are more prone to fractures compared with those free of any endodontic application (2). Although the fractures of ETT have been traditionally associated with loss of elasticity and moisture (3), the main reason is the reduction of dental hard tissue bulk as a result of cavity preparation which is routinely done by using rotary burs (4). Furthermore, microcrack formation occurring during cavity preparation and/or root canal instrumentation renders teeth more susceptible to fractures (5).

Currently, laser technology is being used for many dental procedures including cavity preparation. The absence of vibration, noise and no or minimal need for local anesthesia have been emphasized as the advantages of laser over conventional rotary instruments in the cavity preparation (6, 7). Furthermore, lasers have been reported to allow minimal invasive approach (8). Particularly, Erbium lasers including Er:YAG (AT Fidelis, Fotona, Ljubljana, Slovenia) and Er,Cr:YSGG (WaterLase iPlus, Biolase, Irvine, CA, USA) lasers are contemporary systems used in order to excavate dental

ORCID IDs of the authors: U.A. 0000-0003-3824-2569; F.A. 0000-0002-2782-2608;

'Department of Endodontics, Gaziantep University Faculty of Dentistry, Gaziantep, Turkey ${ }^{2}$ Department of Endodontics, Adıyaman University Faculty of Dentistry, Adıyaman, Turkey ${ }^{3}$ Higher School of Health Services Gaziantep University, Gaziantep, Turkey

Corresponding Author: Uğur Aydın E-mail: ugurdis@gmail.com

Received: 05 January 2017 Revised: 03 February 2017 Accepted: 21 February 2017

DOI: $10.26650 /$ eor.2018.442 
hard tissues (7-9). Following absorption of laser light, dental hard tissues heat above melting point and explode by releasing their mineral content (10).

Microleakage of restorations after cavity preparation with lasers (7-9) and their effectiveness during cavity preparation (10-12) have been previously investigated. However, to the best of our knowledge, fracture strengths of cavities prepared with laser devices and conventional burs have not been compared before. The aim of the present study is therefore to examine the coronal fracture resistance of root-filled teeth after access cavity preparation either with Er,Cr:YSGG, Er:YAG lasers or conventional rotary burs. The null hypothesis of this study is that there is no significant difference between $\mathrm{Er}, \mathrm{Cr}$ :YSGG, Er:YAG and bur groups in terms of fracture resistance.

\section{Materials and methods}

\section{Sample preparation}

The present study was approved by the ethical committee of Gaziantep University (Project number: 2015/125) and verbal constent was obtained from patient in order to use their extracted teeth for the present study. This experiment included 55 intact $(\mathrm{N}=55)$, human mandibular molars of nearly similar dimensions ( $15 \pm 1 \mathrm{~mm}$ mesiodistally; $8 \pm 1 \mathrm{~mm}$ buccolingually), extracted due to periodontal reasons having no decay, filling, or other hard tissue loss. Any remnants over the surface were removed with scalers. Specimens were kept in $0.1 \mathrm{M}$ thymol solution for disinfection at room temperature until the experiment. The samples were randomly distributed into 7 groups including 3 study and 4 control groups by using an on-line randomizing software service. Negative control groups (group 1,2 and 3 ) included 5 teeth per each group $(n=5)$, while study groups (groups 4, 5 and 6) and positive control group (group 7) included 10 teeth per group $(n=10)$. An easy inlet to the root canals is provided in all cavities. A size 15K-file (Sybron Endo, Scafati, Italy) was advanced throughout the canal until its tip was visible at the apical foramen. Working length was calculated as $0.5-1 \mathrm{~mm}$ shorter of this point. Following each instrument, the canals were rinsed with $2 \mathrm{~mL}$ of $\mathrm{NaOCl}$ solution. Root canals were prepared up to an apical diameter of size 40 . Step-back preparation was continued by withdrawing $1 \mathrm{~mm}$ after each file until size 80 file. Coronal one-third was enlarged by using size 2-4 Gates-Glidden burs (Thomas, Bourges, France). Excess irrigants were dried with paper points (Dentplus, Choonchong, Korea). Root canal filling was achieved with lateral condensation technique by using gutta-percha (Dentplus, Choonchong, Korea) and sealer (AD seal, Meta-Biomed, Cheongwon, Korea). Excess gutta-percha was cut with a heating tool from canal tips (Gutta Cut, VDW, Munich, Germany). All cavities were modified to MOD configuration with cylindrical burs to reach a thickness of $2.5 \mathrm{~mm}$ at the buccal occlusal wall, $3.5 \mathrm{~mm}$ at the buccal cemento-enamel junction, $1.5 \mathrm{~mm}$ at the lingual occlusal surface and $2.5 \mathrm{~mm}$ at the lingual cemento-enamel junction by using caliper. Pulp chambers were filled with resin-modified glass-ionomer cement (GC Corporation, Tokyo, Japan) (Figure 1).

\section{Cavity preparation}

The teeth were grouped as follows: Group 1 and Group 4: Access cavities were prepared with diamond round burs (Medin,
Nove Mestona Morave, Czech Republic) attached to a highspeed hand piece under water cooling. Group 2 and Group 5: Access cavities were prepared by using a non-contact tip (R02 Handpiece) attached to Er:YAG laser at a wavelength of 2940 nm (AT Fidelis, Fotona, Ljubljana, Slovenia). The energy settings were; $300 \mathrm{~mJ} 30 \mathrm{~Hz}$ (9W) 6 water (65\%) and 4 air (45\%) in Medium Short Pulse (MSP=100 microseconds) mode for enamel, 225 $\mathrm{mJ} 15 \mathrm{~Hz}$ (3.35 W) 5 water (55\%) and 3 air (35\%) in MSP mode for dentin. Average energy used for each sample was approximately 2700 joule for enamel and 3000 joule for dentin. Group 3 and Group 6: Access cavities were prepared with a non-contact tip Turbo handpiece (MX7 tip) attached to Er,Cr:YSGG laser at a wavelength of $2780 \mathrm{~nm}$ (WaterLase iPlus, Biolase, Irvine, (A, USA). The energy settings were; $8 \mathrm{~W} 20 \mathrm{~Hz} 70 \%$ Air and $80 \%$ water in $\mathrm{H}$ mode for enamel, 6W $15 \mathrm{~Hz} 50 \%$ Air and 70\% Water in Hard Mode ( $\mathrm{H}$ mode $=60$ microseconds) for dentin. Average energy used for each sample was approximately 2800 joule for enamel and 3200 joule for dentin. Group 7: No treatment was applied (intact teeth).

\section{Coronal restoration}

Coronal restorations of groups 4, 5 and 6 were done as follows: After applying self-etching bonding agent (Single Bond Universal Adhesive, 3M ESPE, St. Paul, MN, ABD) for $20 \mathrm{sec}-$ onds, it was gently dried and light-cured for 10 seconds with light-emitting diode device (Valo Cordless, Ultradent Products Inc., South Jordan, UT, USA) at $1000 \mathrm{~mW} / \mathrm{cm}^{2}$ intensity. Cavities were restored with composite resin (Filtek Z550, 3M ESPE, St. Paul, MN, USA) by using incremental technique. Two $\mathrm{mm}$ resin was placed in each layer (Figure 2 ). To provide standardization, the light source was applied by positioning it just over the cusp tips. Following each 10 samples, the density of the light was checked with a dental radiometer (Demetron, Kerr, Orange, CA, USA) because the intensity of light source should not declineunder $1000 \mathrm{~mW} / \mathrm{cm}^{2}$. Coronal segments of the samples in groups 1, 2 and 3 (negative control) were left unfilled. Roots of all samples were embedded in cylinderic molds filled with self-curing polymethylmethacrylate (Imicryl, İstanbul, Turkey) up to cemento-enamel junction.

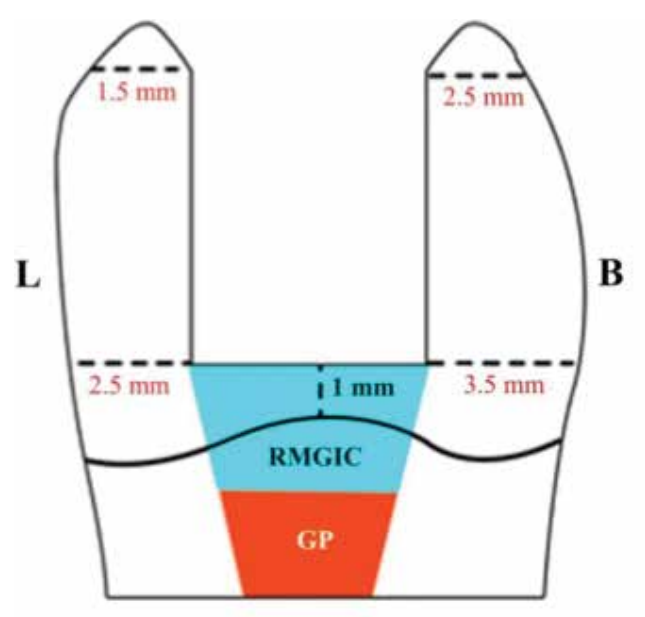

Figure 1. Schematic representation of cavities without coronal restoration.

B: Buccal, L: Lingual, RMGIC: Resin Modified Glass lonomer Cement, GP: Gutta Percha) 


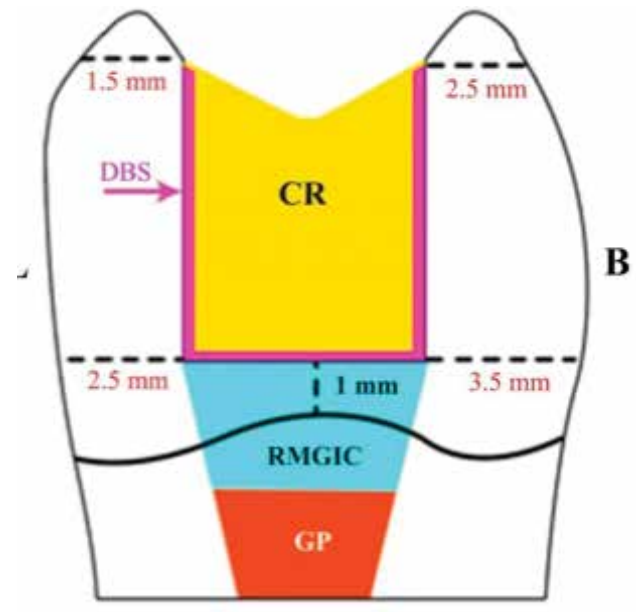

Figure 2. Schematic representation of cavities with coronal restoration. B: Buccal, L: Lingual, RMGIC: Resin Modified Glass lonomer Cement, GP: Gutta Percha, DBS: Dentine Bonding System, CR: Coronal Restoration)

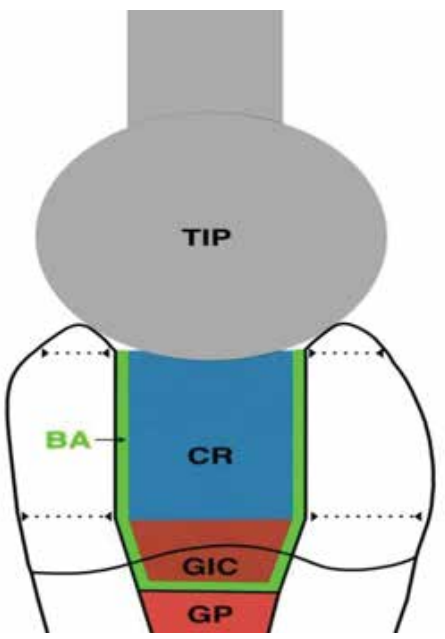

Figure 3. Schematic representation of applying fracture test to the samples. GIC: Glass lonomer Cement GP: Gutta Percha BA: Bonding Agent CR: Coronal Restoration TIP: Spherical tip of the testing machine)

\section{Fracture Test}

All specimens were thermocycled for 5000 cycles between 5 and $55^{\circ} \mathrm{C}$, using a dwell time of 30 seconds in each bath. Following thermocycling process, the samples were placed in a Universal Testing Machine (AGS-X, Shimadzu, Kyoto, Japan). A round-shaped steel tip in $5 \mathrm{~mm}$ diameter was connected to the testing machine in contact with restoration surface, buccal and lingual walls of the teeth (Figure 3). Fracture resistance of each group was measured by applying force parallel to the long axis of each tooth at a crosshead speed of $1 \mathrm{~mm} / \mathrm{min}$ (Figure 4). Force necessary to fracture each tooth was recorded in Newton. Fracture test was applied by another blinded researcher. Fracture modes were classified according to the study of Taha et al. (1); Type 1: Horizontal cuspal fracture above cemento-enamel junction (CEJ) (Restorable). Type 2: Vertical fracture of either lingual or buccal wall above CEJ (Restorable). Type 3: Vertical fracture of either lingual or buccal wall below CEJ (Non-restorable).

\section{Statistical analysis}

Prior to statistical analysis, the normality of the data was analyzed with Shaphiro-Wilk test. Due to normal distribution of the data, statistical analysis was performed with one way analysis of variance (ANOVA) and post-hoc Tukey's Honestly

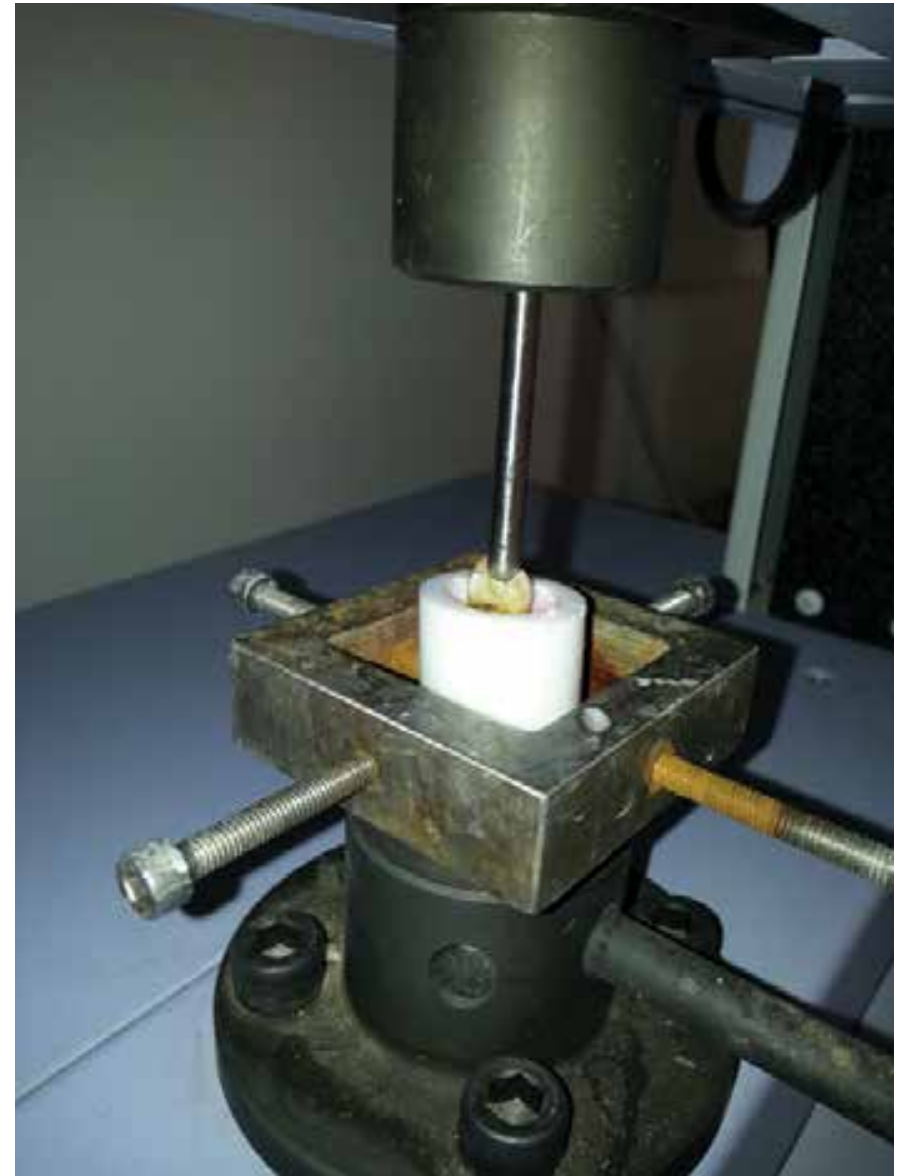

Figure 4. Sample attached to the Universal Testing Machine for fracture test.

Significant Difference (HSD) tests by using Statistical Package for Social Sciences (SPSS) (IBM Corp.; Released 2010. IBM SPSS Statistics for Windows, Version 19.0. Armonk, NY, USA) software. Confidence level was set to $95 \%$ and $p$ values less than 0.05 were considered as statistically significant.

\section{Results}

The mean force required for the fracture to occur in each group in Newton $(\mathrm{N})$ and their standard deviations are presented in Table 1. Fracture resistance of group 7 (intact teeth) was significantly higher than all other groups $(p<0.001)$. Differences between the fracture resistance values of groups 4, 5 and 6 were not significantly different, while they were significantly higher those of the groups 1,2 and $3(p<0.001)$. There were no statistically significant differences between the mean fracture resistances of Group 1, 2 and 3. Fracture modes of the groups are presented in Table 2. The percentage of non-restorable fractures were; $80 \%$ in group $1,100 \%$ in group $2,80 \%$ in group $3,50 \%$ in group $4,50 \%$ in group 5 , and $60 \%$ in group 6 . All fracture occurred in dental hard tissues while coronal restorations were observed to be intact.

\section{Discussion}

Erbium lasers work by ablating water either present within the structure of dental hard tissues or supplied as a spray by laser devices. Ablation causes microstructural changes that include flaking, charring, microcrack and pore formation in dental hard tissues which may lead to fractures. The studies of Meister et al. (13) and Ekwarapoj et al. (14) pointed out that Er:YAG laser ablates endogenous water found in collagen of intertubular den- 
Table 1. Mean fracture resistances and standard deviations of

7 experimental groups. Same superscript symbols indicate no significant difference

\begin{tabular}{lccc} 
Groups & N & Mean & SD \\
\hline 1 Bur cavity & 5 & $375.56^{\dagger}$ & 72.25 \\
\hline 2 Er:YAG cavity & 5 & $469.58^{\dagger}$ & 129.18 \\
\hline 3 Er,Cr:YSGG cavity & 5 & $208.69^{\dagger}$ & 74.08 \\
\hline 4 Bur+composite & 10 & $2249.99^{\ddagger}$ & 402.94 \\
\hline 5 Er:YAG+composite & 10 & $1767.18^{\ddagger}$ & 384.75 \\
\hline 6 Er,Cr:YSGG+composite & 10 & $1930.50^{\ddagger}$ & 442.37 \\
\hline 7 Intact & 10 & $2745.83^{5}$ & 628.17 \\
\hline Total & 55 & 1676.44 & 964.03 \\
\hline
\end{tabular}

Er:YAG: erbium-doped yttrium aluminum garnet laser; Er,Cr:YSGG: erbium, cromium: yttrium scandium gallium garnet laser; SD: standard deviation

Table 2. Fracture modes observed in each group.

\begin{tabular}{lcccc} 
Groups & N & Type 1 & Type 2 & Type 3 \\
\hline 1 Bur cavity & 5 & 0 & 1 & 4 \\
\hline 2 Er:YAG cavity & 5 & 0 & 0 & 5 \\
\hline 3 Er,Cr:YSGG cavity & 5 & 0 & 1 & 4 \\
\hline 4 Bur+composite & 10 & 2 & 3 & 5 \\
\hline 5 Er:YAG+composite & 10 & 3 & 2 & 5 \\
\hline 6 Er,Cr:YSGG+composite & 10 & 2 & 2 & 6 \\
\hline 7 Intact & 10 & 8 & 1 & 1 \\
\hline Total & 55 & 15 & 10 & 30 \\
\hline
\end{tabular}

Er:YAG: erbium-doped yttrium aluminum garnet laser; Er,Cr:YSGG: erbium; cromium: yttrium scandium gallium garnet laser

tine more than exogenous water, while Er,Cr:YSGG laser uses exogenous water more than endogenous water. Franzen et al. (15) found that similar microstructural changes occur if adequate water supply is provided for both type of lasers. We assume that the similarity in the fracture strength values of laser groups is related to providing sufficient amount of water in the present study. In other words, using correct water settings for lasers resulted in similar microstructural changes and thus, similar fracture strength values. Furthermore, results of the present study revealed no significant difference between laser and bur groups. Thus, the null hypothesis was accepted. The results of this study, when combined with those of the previous researches suggest that the fracture of root-filled teeth may be correlated with either the amount of dental hard tissue loss or the micro crack formation during cavity preparation. We also need to highlight that the samples of the present study were prepared from intact teeth and cavities were modified as MOD type by using high power settings in order to provide standardization. Previous studies indicated a positive correlation of power settings with the amount of ablated tissue $(14,16)$. During clinical practice, lower power settings, which are only sensitive to decayed tissue, can be used and, by doing this, both microstructural damages can be minimized and more conservative cavities can be prepared. Thus, less hard tissue removal leads to increased resistance. This was also confirmed by Corona et al. (17) and Fornaini et al. (18). Franzen et al. (15) reported that minimal invasive cavities can be prepared and patient comfort can be enhanced by using Erbium lasers during cavity preparation. Accordingly, despite the present study found that fracture resistance did not vary either with burs or with laser, other advantages of cavity preparation with laser mentioned above may also motivate the clinicians to use Erbium lasers for cavity preparation. Further in vivo and in vitro studies with lower power settings may be beneficial to explore such advantages of laser devices.

The results of the present study further indicated that the reinforcing properties of the coronal restoration is more important than the technique used for access cavity preparation because as seen in Table 1, all coronally restored groups (4, 5 and 6) have significantly higher fracture strengths compared to non-restored groups (1, 2 and 3). In the study of Sengun et al. (19), it was reported that restoring the coronal portion of the root-filled teeth with appropriate materials compensates the loss of hard tissue bulk and reinforces dental hard tissues. Thus, it can be stated that the quality of the coronal restorative material are more important than the technique used for cavity preparation in terms of fracture strength.

Re-restorability of root-filled teeth following fracture is another issue of concern. If fracture occurs in non-restorable form, extraction may be required. However, according to our results, $50-60 \%$ of the fracture modes in coronally restored groups are non-restorable, while this percentage is $90-100 \%$ in non-restored groups. This may be due to the irrelevancy of cavity preparation techniques with the reinforcing capacity of coronal restoration. Better strengthening of coronal restoration results in more restorable fracture modes (20). Although different cavity preparation techniques have been used in the present study, all coronal restorations were performed with the same material in a similar manner.

Thermocycling was performed in the present study to simulate aging effects of intra-oral conditions. Eakle (21) stated that the thermocycling process reduces the strengthening capacity of resin restorations, therefore, long-term use of the root-filled and restored teeth can be simulated. The study of Kruzic et al. (22) reported that micro cracks leading to fractures occur as a result of fatigue cycling rather than the force load itself. For these reasons, samples of present study were subjected to thermocycling before the fracture strength tests.

Zadik et al. (23) stated that mandibular molars are the most likely to be extracted following endodontic treatment resulting from fractures compared to other teeth. For this reason, mandibular molars were included in the present study. Dental hard tissue bulk remained following caries removal and cavity preparation is another risk factor in terms of fracture occurrence. Tang et al. (24) found that MOD cavities carry more fracture risk compared to $\mathrm{MO}$ and OD cavities. In the present study, all cavities were modified to MOD configuration to increase fracture risk. Furthermore, all fractures have notably occurred between dental tissues and composite restoration (adhesive failure). This may be related to the low thickness of the cavity walls, particularly at the cavity base ( $3.5 \mathrm{~mm}$ for buccal, $2.5 \mathrm{~mm}$ for lingual) which may have led to fracture of these thin walls before composite restoration. Fracture resistance values were determined with a universal testing machine by applying force parallel to the long axis of teeth. However, magnitude and directions of physiological chewing forces may be different from those of simulators (25). Therefore, the results of in vitro studies must be confirmed by clinical trials. 


\section{Conclusion}

Within the limitations of this in vitro study, it can be stated that preparing access cavities with either laser or bur does not have any deleterious effect on the fracture resistance of teeth with root canal treatment.

Ethics Committee Approval: The present study was approved by the ethical committee of Gaziantep University (Project number: 2015/125).

Informed Consent: Verbal informed consent was obtained from the parents of the patients/patients who participated in this study.

Peer-review: Externally peer-reviewed.

Author Contributions: UA, FA and ST designed the study and generated the data. FA and ST gathered the data. UA and DAB analyzed the data. FA and ST wrote the majority of the original draft. UA participated in writing the paper. All authors approved the final version of the paper.

Conflict of Interest: The authors have no conflicts of interest to declare.

Financial Disclosure: The authors declared that this study has received no financial support.

Türkçe öz: Konvansiyonel frez, ER:YAG ve ER,CR:YSGG lazerler ile kavite açılan kanal tedavili dişlerin kırılma dirençleri. Amaç: Bu çalışmanın amacı, konvansiyonel frezler, Er:YAG ve Er,Cr:YSGG lazerler ile giriş kavitesi açılmasının ardından dişlerin kırılma dirençlerinin karşılaştırılmasıdır. Gereç ve Yöntem: Elli beş alt çene azı dişi, 3 negatif grup (grup 1, 2, $3 ; n=5), 3$ çalışma grubu (grup 1, 2, 3; $n=10$ ) ve 1 pozitif kontrol grubu (sağlam dişler; $n=10$ ) olmak üzere 7 gruba ayrıldı. Grup 1, 2 ve 3' ün giriş kaviteleri sirasıyla konvansiyonel frez, Erbium-doped yttrium aluminum garnet laser (Er:YAG) ve Erbium, cromium: yttrium scandium gallium garnet laser (Er,Cr:YSGG) ile açıldı. Kanalların doldurulmasının ardından koronal kısımlar restore edilmeden bırakıldı. Grup 4, 5 ve 6' nın giriş kaviteleri sırasıyla konvansiyonel frez, Er:YAG ve Er,Cr:YSGG ile açıldı. Kanalların doldurulmasının ardından koronal kısımlar kompozit rezin ile restore edildi. Termosiklüs sonrası, kırılma dirençleri, Universal Test Cihazı ile ölçüldü. Her bir örneği kırmak için gereken ortalama kuvvet Newton olarak kaydedildi ve veriler istatistiksel olarak değerlendirildi. Bulgular: Sağlam dişlerden oluşan Grup 7'nin kırılma direnci, diğer gruplardan anlamlı düzeyde yüksek bulundu $(p<0,001)$. Grup 4, 5 ve 6'nın kırılma dirençleri arasında farklıık izlenmezken Grup 1, 2 ve 3'ten anlamlı düzeyde fazla bulundu ( $p<0,001)$. Grup 1, 2 ve 3 de ölçülen $k ı-$ rılma dirençleri arasında fark bulunmamıştır. Sonuç: Giriş kavitelerinin lazer veya frezler ile hazırlanması kırılma direncini etkilemedi. Anahtar kelimeler: Frez; koronal dayanım; Er,Cr:YSGG; Er:YAG; kırılma direnci

\section{References}

1. Taha NA, Palamara JE, Messer HH. Fracture strength and fracture patterns of root filled teeth restored with direct resin restorations. J Dent 2011; 39: 527-35. [CrossRef]

2. Pilo R, Metzger Z, Brosh T. Effect of root morphology on the susceptibility of endodontically treated teeth to vertical root fracture: An ex-vivo model. J Mech Behav Biomed Mater 2017; 69: i267-74.

3. Assif D, Nissan J, Gafni Y, Gordon M. Assessment of the resistance to fracture of endodontically treated molars restored with amalgam. J Prosthet Dent 2003; 89: 462-5. [CrossRef]

4. Soares PV, Santos-Filho PC, Martins LR, Soares CJ. Influence of restorative technique on the biomechanical behavior of endodontically treated maxillary premolars. Part i: Fracture resistance and fracture mode. J Prosthet Dent 2008; 99: 30-7. [CrossRef]

5. Kim HC, Lee MH, Yum J, Versluis A, Lee CJ, Kim BM. Potential relationship between design of nickel-titanium rotary instruments and vertical root fracture. J Endod 2010; 36(7): 1195-9. [CrossRef]
6. Kirzioglu Z, Gurbuz T, Yilmaz Y. Clinical evaluation of chemomechanical and mechanical caries removal: Status of the restorations at 3, 6, 9 and 12 months. Clin Oral Investig 2007; 11:6976. [CrossRef]

7. Bahrololoomi Z, Heydari E. Assessment of tooth preparation via er:Yag laser and bur on microleakage of dentin adhesives. $J$ Dent (Tehran) 2014; 11: 172-8.

8. Baghalian A, Nakhjavani YB, Hooshmand T, Motahhary P, Bahramian $\mathrm{H}$. Microleakage of er:Yag laser and dental bur prepared cavities in primary teeth restored with different adhesive restorative materials. Lasers Med Sci 2013; 28: 1453-60. [CrossRef]

9. Fattah T, Kazemi H, Fekrazad R, Assadian H, Kalhori KA. Er,cr:Ysgg laser influence on microleakage of class $\mathrm{V}$ composite resin restorations. Lasers Med Sci 2013; 28: 1257-62. [CrossRef]

10. DenBesten PK, White JM, Pelino JE, Furnish G, Silveira A, Parkins FM. The safety and effectiveness of an er: Yag laser for caries removal and cavity preparation in children. Medical Laser Application 2001; 16: 215-22. [CrossRef]

11. Neves Ade A, Coutinho E, De Munck J, Van Meerbeek B. Caries-removal effectiveness and minimal-invasiveness potential of caries-excavation techniques: A micro-ct investigation. J Dent 2011; 39: 154-62. [CrossRef]

12. Eberhard J, Bode K, Hedderich J, Jepsen S. Cavity size difference after caries removal by a fluorescence-controlled er:Yag laser and by conventional bur treatment. Clin Oral Investig 2008; 12: 311-8. [CrossRef]

13. Meister J, Franzen R, Forner K, Grebe H, Stanzel S, Lampert F, Apel C. Influence of the water content in dental enamel and dentin on ablation with erbium yag and erbium ysgg lasers. J Biomed Opt 2006; 11: 34030. [CrossRef]

14. Ekworapoj P, Sidhu SK, McCabe JF. Effect of different power parameters of er,cr:Ysgg laser on human dentine. Lasers Med Sci 2007; 22: 175-82. [CrossRef]

15. Franzen R, Kianimanesh N, Marx R, Ahmed A, Gutknecht N. Fracture forces of dentin after surface treatment with high speed drill compared to er:Yag and er,cr:Ysgg laser irradiation. Anal Cell Pathol (Amst) 2016; 2016: 8517947. [CrossRef]

16. Rizoiu I-M, DeShazer LG. New laser-matter interaction concept to enhance hard tissue cutting efficiency. In Society of Photo-Optical Instrumentation Engineers (SPIE) Conference Series: 1994; 309-17. [CrossRef]

17. Corona SA, de Souza AE, Chinelatti MA, Borsatto MC, Pecora JD, Palma-Dibb RG. Effect of energy and pulse repetition rate of er: Yag laser on dentin ablation ability and morphological analysis of the laser-irradiated substrate. Photomed Laser Surg 2007; 25: 26-33. [CrossRef]

18. Fornaini C, Petruzzella S, Podda R, Merigo E, Nammour S, Vescovi P. Er:Yag laser and fractured incisor restorations: An in vitro study. Int J Dent 2012; doi:10.1155/2012/617264. [CrossRef]

19. Sengun A, Cobankara FK, Orucoglu H. Effect of a new restoration technique on fracture resistance of endodontically treated teeth. Dental Traumatology 2008; 24: 214-9. [CrossRef]

20. Akman S, Akman M, Eskitascioglu G, Belli S. Influence of several fibre-reinforced composite restoration techniques on cusp movement and fracture strength of molar teeth. International endodontic journal 2011; 44: 407-15. [CrossRef]

21. Eakle W. Effect of thermal cycling on fracture strength and microleakage in teeth restored with a bonded composite resin. Dental Materials 1986; 2: 114-17. [CrossRef]

22. Kruzic JJ, Nalla RK, Kinney JH, Ritchie RO. Mechanistic aspects of in vitro fatigue-crack growth in dentin. Biomaterials 2005; 26 : 1195-204. [CrossRef]

23. Zadik Y, Sandler V, Bechor R, Salehrabi R. Analysis of factors related to extraction of endodontically treated teeth. Oral Surg Oral Med Oral Pathol Oral Radiol Endod 2008; 106: e31-5. [CrossRef]

24. Tang W, Wu Y, Smales RJ. Identifying and reducing risks for potential fractures in endodontically treated teeth. J Endod 2010; 36: 609-17. [CrossRef]

25. Jagadish S, Yogesh BG. Fracture resistance of teeth with class 2 silver amalgam, posterior composite, and glass cermet restorations. Oper Dent 1990; 15: 42-7. 